\title{
Evaluation of pressing time in the production of edge glued panel with adhesive polyurethane derived from castor oil
}

\author{
Richard Eduard Mölleken ${ }^{1 *}$, Rosilani Trianoski ${ }^{2}$, Salvador Claro Neto ${ }^{3}$, Caroline Rodrigues Pereira ${ }^{1}$, \\ Setsuo Iwakiri ${ }^{2}$ and Elaine Cristina Azevedo ${ }^{1}$
}

*Correspondence:

richard_molleken@hotmail. com

${ }^{1}$ Universidade Tecnológica Federal do Paraná, Curitiba, Rebouças 80230-901, Brazil Full list of author information is available at the end of the article

\begin{abstract}
Edge-glued panels are composed by the lateral and top gluing with adhesives of solid battens. These panels use small pieces of wood, offering an optimal usage of forest resources and the development of higher value-added products. The adhesive generally used to produce the panels are the synthetic ones (PVA or EPI). The polyurethane derived from castor oil may arise an alternative to replace the adhesives derived from non-natural origin, because it has no solvent in its composition, is a biodegradable material and it comes from a renewable resource. The bonding quality of this panel was performed according to BS EN 13353, which specify the minimum resistance values for panels under different humidity and temperature conditions applied to the international market. In this context, the aim of this paper was to evaluate the lateral gluing quality of Pinus taeda panels using the polyurethane derived from castor oil, as well as assess the pressing time effect on the bonding quality. The adhesive was applied into the battens surface in weight of $180 \mathrm{~g} / \mathrm{m}^{2}$. The panels were put into a cold press machine for 1, 2, 4, 8 and $24 \mathrm{~h}$, totalizing five conditions and eight together/replications. The bonding quality of this panel was performed according to BS EN 13353 and BS EN 13354, under different humidity and temperature conditions. The results were submitted to statistical analysis by outlier tests, normality test, homogeneity variance, analysis of variance and mean comparison, all with $95 \%$ reliability. The polyurethane showed acceptable values to EN-13353 for $4 \mathrm{~h}$ in the press machine. The test for critical humidity and temperature conditions showed a reduction in the adhesive bond strength, but still acceptable to EN-13353. Under these circumstances, it is concluded that the polyurethane derived from castor oil may be an alternative to produce lateral glued panels for dry conditions and internal and external applications for humid conditions.
\end{abstract}

Keywords: EGP, Bonding quality, Polyurethane

\section{Background}

Reconstituted wood products enables the forest resources conservation because they use the union of different wood sizes and shapes [1]. With the expanding use of these products, it is necessary to understand the interface interaction between the wood and the adhesive used to manufacture glued products [2].

(c) 2016 The Author(s). This article is distributed under the terms of the Creative Commons Attribution 4.0 International License (http://creativecommons.org/licenses/by/4.0/), which permits unrestricted use, distribution, and reproduction in any medium, provided you give appropriate credit to the original author(s) and the source, provide a link to the Creative Commons license, and indicate if changes were made. 
Among the various reconstituted wood products, stands out the Edge Panel-"EGP", is Among the reconstituted wood products, the Edge Panel-"EGP", stands out, this panel is composed of battens, obtained from sawn wood, united by lateral gluing and may or may not be joined at the top by amendments such as finger joint [3]. The EGP adds value and increase its industrial productivity, due to the use of narrow or short battens that would be discarded by sawmills and flooring industries. The raw material can be better used, besides reduce costs, once the wood is the major production costs. [1, 2].

The Brazilian production of these panels comes from planted forest species of Pine, Eucalyptus and Teak. The Pine species, mainly Pinus taeda, are the most used due to its mass specific characteristics and its chemical properties suitable to bond, creating a satisfactory line of glue or a good performance $[3,4]$.

The adhesives most used in the battens bonding process are PVAc (polyvinyl acetate chloride) and EPI (polymeric emulsion of isocyanate) [5], which are petroleum-based, non-biodegradable and can cause damage to the human health and the environment. Adhesives derived from biomass, clean and biodegradable, come as an important alternative [6-8].

The polyurethane derived from castor oil do not cause damage to either humans or the environment, comes from a natural and renewable resource. The castor oil used in the manufacturing process of the adhesive is obtained from the seed of the "Ricinus communis" plant, found in tropical and subtropical regions, is an alternative to replace adhesives derived from non-natural origins [7, 9].

When evaluate new adhesives for bonding wood, it should consider several aspects, such as the adhesive interaction with the wood's physical and chemical properties, the physicochemical properties of the adhesive formulation, weight, lifetime, cure type or polymerization pressing time, use conditions, among others.

The pressing time is an important parameter to be established, once the shorter the time, the higher the productivity will be, resulting in higher daily production with low energy consume [10]. The pressing time is determined by a big enough hardness to prevent the surfaces detachment, which may represent a well cured bond line and present a high wood failure percentage $[11,12]$.

To evaluate the pressing time effect on the quality on the surfaces bonding as well as if the adhesive is suitable for certain uses or has some moisture resistance, tests are performed under different conditions of temperature and humidity.

The European standard EN-204 establishes four resistance classes for adhesives: the D1 class comprises adhesives of interior use, for environments where the equilibrium moisture content do not exceed $15 \%$; D2 class includes adhesives of indoor use with fast and sporadic exposures to moisture, but the equilibrium moisture content should not exceed $18 \%$; D3 class includes adhesives of indoor use with quick but frequent exhibitions to moisture and outdoor adhesives with no direct weather exposure; and D4 class are indoor adhesives used with frequent and long-lasting exhibitions to moisture and outdoor ones used with adequate protection [13].

The European standard EN-13354 [14], on the other hand, describes the procedures for evaluation of bonding quality of solid wood panels. To classify them, it is necessary to do different treatments in water immersion at $20^{\circ}$ for $24 \mathrm{~h}$, if the panels is for dry conditions; boil for $6 \mathrm{~h}$ and cool it for $1 \mathrm{~h}$ in water at $20^{\circ} \mathrm{C}$ if the panels are used in wet 
conditions; and a humidity and temperature cycle (boil for $4 \mathrm{~h}$, then it is put into an oven for 16 to $20 \mathrm{~h}$ at $60^{\circ} \mathrm{C}$, then boil for over $4 \mathrm{~h}$ and one cool it time in water at $20^{\circ} \mathrm{C}$ ), if the panels are for outdoors use.

Considering the importance of an alternative adhesive for wood bonding, as well as the maximization of the production process due pressing time, this paper aims to evaluate the lateral gluing quality of Pinus taeda panels using the polyurethane derived from castor oil, as well as assess the pressing time effect on the bonding quality.

\section{Methods}

\section{Materials}

The Pinus taeda wood used was donated by BrasPine Madeiras Ltda Company. The wood was provided in form of flattened and dried battens with $31.5 \mathrm{~cm}$ (length) $\times 4.0 \mathrm{~cm}$ (width) $\times 2.5 \mathrm{~cm}$ (thickness), to make the bonded joints.

The adhesive used for bonding of the joists was the polyurethane derived from castor oil, Polibond ${ }^{\circledR}$, donated by Cequil Company. For gluing the wood parts, the preparation of the polyurethane was according to the manufacturer's orientations with weight proportion of polyol and prepolymer of 1: 1 .

\section{Methods}

\section{Apparent density of wood}

The wood's apparent density was determined by measuring the dimensions and weights of all the parts to be bonded according to standard COPANT 461 [15].

\section{Bonding}

The battens were bonded with polyurethane, which was applied with a spatula in one side of the parts in weight of $180 \mathrm{~g} / \mathrm{m}^{2}$. The two pieces were pressed with $6.45 \mathrm{kgf} / \mathrm{cm}^{2}$ exerted by means of a torque wrench $(30 \mathrm{Nm})$. The experiment consisted in the following pressing time: $1,2,4,8$ and $24 \mathrm{~h}$, a total of 5 condition and 8 together/replications. After bonding, the joints were placed in a climatic chamber at $20 \pm 3{ }^{\circ} \mathrm{C}$ and relative humidity of $65 \pm 5 \%$ for 30 days and then sectioned for preparation of specimens for evaluation of quality bonding, as shown in Fig. 1a. Were obtained 40 specimens per treatment, where for each pretreatment 10 of it were tested as samples and in the format of specimens, Fig. 1b, as suggested by the standard EN 13354 [14].

\section{Treatment}

The treatments determined by standard EN-13353 [14] and EN-13354 [16] for evaluation of bonding quality solid wood panels and adopted in this study were:

- SPW/1-Dry conditions: $24 \mathrm{~h}$ in water $(20 \pm 3)^{\circ} \mathrm{C}$;

- SWP/2-Humid conditions: $6 \mathrm{~h}$ in boiling water, $1 \mathrm{~h}$ cooling in water $\left(20 \pm 3{ }^{\circ} \mathrm{C}\right)$;

- External conditions: $4 \mathrm{~h}$ in boiling water-16 to $20 \mathrm{~h}$ drying $\left(60 \pm 3{ }^{\circ} \mathrm{C}\right)-4 \mathrm{~h}$ in boiling water $-1 \mathrm{~h}$ cooling in water $\left(20 \pm 3{ }^{\circ} \mathrm{C}\right)$. 

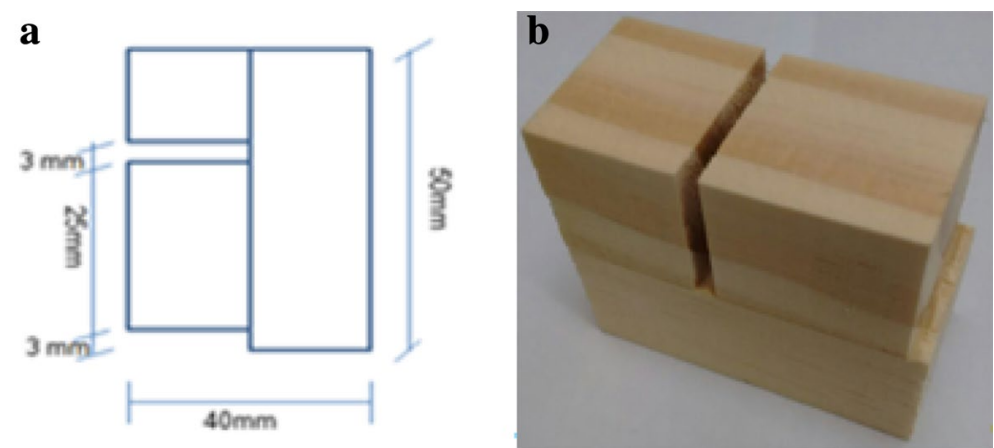

Fig. 1 Sketches of the specimen in the glued battens: a measures according to EN 13354 and $\mathbf{b}$ real sample

In addition to the treatments mentioned above were also tested, 10 specimen for dry test (air-conditioned temperature of $20 \pm 3{ }^{\circ} \mathrm{C}$ and relative humidity of $65 \pm 5 \%$ ), to serve as a benchmark and ignoring the adhesive resistance class for this purpose.

\section{Mechanical tests}

Shear strength tests on the glue line were conducted according to the procedures described in the standard EN-13354 [16] and the results were compared with the requirements established in standard EN-13353 [14]. The machine used was one of Universal Testing Machine Emic brand, with capacity of 2 tons. The test speed was $3 \mathrm{~mm} /$ $\mathrm{min}$, so that the break of the test pieces occurred within the time range of $60 \pm 30 \mathrm{~s}$ as prescribed by the standard adopted.

The evaluation of the wood failure percentages in the rupture surface of the glue line were made according to EN 314-1 [17].

\section{Statistical treatment}

It was used the statistical program Statgraphics Centurion 16.1.11 and the data submitted to Grubbs tests to assess the occurrence of outliers, Kolmogorov to test the adherence of data Bartlett for homogeneity of variance and analysis of variance. When rejected the null hypothesis was applied to compare the means of Tukey, with $95 \%$ probability.

\section{Results and discussion}

The average apparent density of Pinus taeda was $553.29 \mathrm{~kg} / \mathrm{m}^{3}$ with $14.17 \%$ of coefficient of variation. According to USDA [18] the apparent density of this species had low values, but can be found differences due the influence of some variables such as different ages, origins, growing conditions and test methods. Klock [19] found apparent density values ranging from 364 to $467 \mathrm{~kg} / \mathrm{m}^{3}$, Ballarin et al. [20] equal to $605 \mathrm{~kg} / \mathrm{m}^{3}$ and Trianoski et al. [21] equal to $500 \mathrm{~kg} / \mathrm{m}^{3}$.

According to Vick [3] softwoods are classified as easy woods to glue, with theoretically good penetration of adhesives. Iwakiri [1], adds that low-mass woods specifies have good permeability, which have significant influence on the adhesiveness between the materials, because the arrangement of the voids will end with the penetration of the adhesive, promoting a mechanical bond with the wood and the more permeable the largest timber will be the penetration of this in the cavities cell. 
Table 1 shows the average shear strength results of the glue line shear stress, the 5th percentile lower and the percentage of failures in the wood after each treatment. It is noteworthy that the average of results to the mentioned properties for $1 \mathrm{~h}$ of pressing time for all treatments were not possible to determine, for during the phase of preparation of the specimens, after gluing, all broke glue line, resulting in a $0 \%$ wood failure, characterized as a weak adhesive bond. Thus, it can be stated that the $1 \mathrm{~h}$ pressing time is insufficient to perform the wood bonding with polyurethane.

The average strength of the glue line shear provided for $2 \mathrm{~h}$ pressing time was the lowest for all treatments (dry, wet, boiling and cycle), its values ranging from 1.54 to $2.38 \mathrm{MPa}$. Analyzing the 5th percentile lower the resistance of the side glue shear line, all treatments with this pressing time did not reach the minimum value of $2.5 \mathrm{MPa}$ minimum requirement recommended by EN 13353 [16] for solid wood panels, featuring as a weak link. The percentage of wood failure got very low values ranging from 1 to $8 \%$, not reaching the minimum value of $40 \%$ wood failure required by EN 13353 [16].

The 24-hour pressing time gave the highest shear strength values of the line of glue for wet and dry treatments (9.96 and $5.47 \mathrm{MPa})$. As for the boil treatment cycle, the highest values were found for $8 \mathrm{~h}$ pressing time (4.93 and $4.85 \mathrm{MPa})$. However, the 5 th percentile lower than required by the standard in all treatments was greater for $24 \mathrm{~h}$ pressing time treatment. Regardless, for $4 \mathrm{~h}$ pressing time the requirement in the EN 13353 [16] to the 5th percentile less as it was fulfilled for all treatments, featuring polyurethane as a structural adhesive for this pressing time.

Table 1 Average results of the shear strength and percent of wood failure for the treatments, dry, humid, boiling and cycle

\begin{tabular}{lcllr}
\hline Treatment & Pressing time (h) & Shear strength (MPa) & Wood fail- \\
\cline { 3 - 5 } & & Average & 5th percentile lower & ure (\%) \\
\hline Dry & 2 & $2.38 \mathrm{c}(49.16)$ & 1.38 & 1 \\
& 4 & $8.60 \mathrm{~b}(12.03)$ & 7.53 & 99 \\
& 8 & $9.53 \mathrm{ab}(10.24)$ & 8.34 & 79 \\
Humid & 24 & $9.96 \mathrm{a}(10.06)$ & 8.43 & 83 \\
& 2 & $2.97 \mathrm{~b}(52.28)$ & 1.32 & 8 \\
& 4 & $5.16 \mathrm{a}(6.12)$ & 4.31 & 26 \\
Boiling & 8 & $5.01 \mathrm{a}(13.90)$ & 4.42 & 30 \\
& 24 & $5.47 \mathrm{a}(10.15)$ & 5.09 & 34 \\
& 2 & $1.54 \mathrm{c}(49.50)$ & 0.74 & 27 \\
& 4 & $4.01 \mathrm{~b}(15.85)$ & 2.99 & 39 \\
Cycle & 8 & $4.93 \mathrm{a}(11.88)$ & 4.12 & 36 \\
& 24 & $4.64 \mathrm{ab}(5.54)$ & 4.34 & 5 \\
& 2 & $1.68 \mathrm{~b}(51.80)$ & 0.56 & 41 \\
& 4 & $4.19 \mathrm{a}(14.05)$ & 3.40 & 10 \\
\hline
\end{tabular}

Averages followed by the same letter in each pre-treatment did not differ significantly by Tukey test at the level of $95 \%$ reliability

Results in parentheses refer to the coefficient of variation

Values in italics meets the requirements of EN 13354: 2003 (5th percentile $\geq 2.5 \mathrm{MPa}$ ) 
For dry treatment, it was found that the $24 \mathrm{~h}$ had the highest average pressing shear strength, however, is statistically equal to $8 \mathrm{~h}$ pressing time. The pressed together at time of $4 \mathrm{~h}$, although they have been shown statistically less than the time $24 \mathrm{~h}$ had a high shear strength, as well as small differences in the lower 5th percentile. Since compared with the $8 \mathrm{~h}$ pressing time, the bonded joints with $4 \mathrm{~h}$ showed resistance statistically equal shear each other, showing that the permanence of the substrate by the double time under pressure is unnecessary or even six times more when the pressing time is $24 \mathrm{~h}$, which directly implies productivity and energy consumption, high cost in the production process of the panels EGP items. Another fact to be noted that deserves special attention concerns the failure of the wood with the $4 \mathrm{~h}$ pressing time averaged $99 \%$, indicating that this condition the adhesive already promotes excellent adhesion and shows much stronger than wood.

In humid processing, i.e., testing of specimens after $24 \mathrm{~h}$ of immersion in water, except for $2 \mathrm{~h}$ pressing time, which identified that is insufficient time to promote the union of the substrates, were not found Statistically significant differences between the remaining time ( 4,8 and $24 \mathrm{~h}$ ), confirming that the $4 \mathrm{~h}$ time generates a good gluing quality. It was also observed that the values of the 5th percentile were very close between the three mentioned treatments and all meet the minimum requirement of $2.50 \mathrm{MPa}$, mentioned by EN-13353 [16]. For this test condition, it is noted further that there was a reduction in the mean wood failure (and resistance) actually provided by the action of water in the glue line, however, even with this reduction in the values, the panel it is approved according to the SWP/1 requirement and can be widely used in dry environments.

In relation to the treatment of $6 \mathrm{~h}$ boil with subsequent cooling in cold water for $1 \mathrm{~h}$, it was found that the $8 \mathrm{~h}$ pressing time showed the highest mean value of shear strength being statistically equal to $24 \mathrm{~h}$ pressing time and statistically superior to $4 \mathrm{~h}$ pressing time and, consequently, to $2 \mathrm{~h}$ pressing time, which showed low performance. However, it appears that the $4 \mathrm{~h}$ pressing time is statistically equal to the $24 \mathrm{~h}$ pressing time indicating that this time may be adopted safely press on the panels. Except for the condition produced with $2 \mathrm{~h}$ pressing time, all the other times had five percentile lower than $2.50 \mathrm{MPa}$ and approved by the reference standard for use in humid conditions (SWP/2). Low failure of wood were found, reflecting the negative effect of humidity and temperature on the samples.

In the course of treatment, except for the $2 \mathrm{~h}$ pressing time, it is observed statistically significant differences were found between the shear strength of other times. The three pressing time (4, 8 and $24 \mathrm{~h}$ ) also showed a value of the lower five percentile higher than 2.50 MPa, indicating that the panels can be used outdoors. Low flaws in the wood were observed confirming the negative effect of drastic humidity temperature conditions.

In general, it is noted that as the samples/specimens are subjected to moisture and temperature there is no strength reduction and failure of the timber. This occurs due to the action of these agents in the line of glue, which promote the breakdown of the chemical, physical and mechanical connections between adhesive and wood.

Another factor relates to the coefficient of variation for samples, the $2 \mathrm{~h}$ pressing time provided a high variability. This variability can be explained by the low quality of bonding, generated by the poor penetration of the adhesive into wood as well as the incomplete polymerization under pressure, where small force variations supported by the body 
of evidence of this treatment resulted in high death rates. The increase in the number of specimens for treatment and test condition (pre-treatment) could reduce the range of values, however, it is noteworthy that the minimum sampling suggested by the standard was respected and under the same number of samples and test conditions, the treatment produced with only $2 \mathrm{~h}$ pressing showed high coefficient of variation, i.e., the variability is most associated to the pressing time than the number of specimens per treatment test condition.

In comparison with results available in the literature, Lopes et all [22] using singlecomponent polyurethane adhesive for high frequency pressing scores a shear strength for the treatment of $9.02 \mathrm{MPa}$ dry and is similar to that observed in this study.

Also in relation to the study of Lopes et all [22], to evaluate other types of adhesives, such authors obtained the following results shear: $8.17 \mathrm{MPa}$ (PVAc) and $8.15 \mathrm{MPa}$ (EPI). Silver [9] obtained shear strength values equal to $2.28 \mathrm{MPa}$ for PVAc adhesive (dry). Comparing these results with those obtained in this research, it appears that the polyurethane adhesive derived from castor oil, is more resistant than the PVAc and the EPI, but in contrast, the pressing time is greater.

In general, it appears that from $4 \mathrm{~h}$ of pressing is not detected statistically significant differences for resistance to the glue line shear, indicating that this pressing time $(4 \mathrm{~h})$ is sufficient to obtain an adhesive bond with good resistance, which reaches the minimum requirement of the standard used for different usage conditions (dry interior, humid inside and outside). Thus, there is the need to spend more time and energy to produce laterally glued panels with polyurethane as well, are encouraged studies to evaluate intermediate pressing times between 2 and $4 \mathrm{~h}$ for example $3 \mathrm{~h}$, which will reflect in reduction of production costs as well as productivity.

\section{Conclusions}

The average apparent density for forest species Pinus taeda was $553.29 \mathrm{~kg} / \mathrm{m}^{3}$ and higher than that found in the literature.

The pressing time of 1 to $2 \mathrm{~h}$ under the conditions of this study is insufficient to promote a quality connection, according to EN 13353.

The pressings conditions for 4, 8 and $24 \mathrm{~h}$, meets the standard EN 13353 and in most cases are statistically equal.

It is recommended the $4 \mathrm{~h}$ pressing time for Pinus taeda EGP production using polyurethane adhesive base of castor oil.

Authors' contributions

REM, CRP and RT participated in performing the experiments and writing of the manuscript, SI performed the statistical analysis and contributed to the writing of the manuscript, ECA and SCN conceived the study, participating in its design and coordination, helping to drafting the manuscript. All authors read and approved the final manuscript.

\section{Author details}

${ }^{1}$ Universidade Tecnológica Federal do Paraná, Curitiba, Rebouças 80230-901, Brazil. ${ }^{2}$ Universidade Federal do Paraná, Curitiba, Jardim Botânico 80210-170, Brazil. ${ }^{3}$ Universidade de São Paulo, São Carlos, Centro 13567-970, Brazil.

Acknowledgements

The authors express its gratitude to Fundação Araucária, FAPESP, CAPES and CNPq for financial support to the laboratories involved. Companies BrasPine madeiras Ltda and Cequil Ltda, by grants from wood and adhesive. 
Received: 7 April 2016 Accepted: 11 June 2016

Published online: 23 June 2016

\section{References}

1. Iwakiri S. Painéis de Madeira reconstituída. Curitiba: FUPEF; 2005

2. Bila NF. Avaliação da qualidade de juntas coladas de seis espécies de madeiras tropicais da Amazônia. 2014. p. 74 Dissertação de Mestrado. UFPR, Curitiba.

3. Vick CB. Adhesive Bonding of Wood Materials. U.S. PRODUCTS LABORATORY. Wood handbook — Wood as an engineering material. Gen. Tech. Rep. FPL_GTR_113. Department of Agriculture, Forest Service, Forest Products Laboratory. 1999. Chapter 9. p. 463 Madison: US.

4. Associação Brasileira da Indústria de Madeira Processada Mecanicamente (ABIMCI). Estudo setorial 2009: Indústria de madeira processada mecanicamente: ano base 2008. 2009. p. 48 Curitiba.

5. Almeida VC. Avaliação do potencial de uso de resíduos de madeira tropical para produção de painéis colados lateralmente-EGP. UFPR: Tese de Doutorado; 2013.

6. Araújo LCR. Contribuição ao estudo dos poliuretanos flexíveis derivados de óleo de mamona determinando suas propriedades físicas e químicas. IQSC: Tese de Doutorado; 1998.

7. Azambuja MA. Estudo experimental de adesivos para fabricação de madeira laminada colada: avaliação da resistência de emendas dentadas, da durabilidade e de vigas. IQSC: Tese de Doutorado; 2006.

8. Azevedo EC. Efeito da radiação nas propriedades mecânicas do adesivo de poliuretana derivado do óleo de mamona. UFPR: Tese de Doutorado; 2009.

9. Marinho NP, Nascimento EM, Nisgoski S, Magalhães WLE, Neto SC, Azevedo EC. Caracterização Física e Térmica de Compósito de Poliuretano Derivado de Óleo de Mamona Associado com Partículas de Bambu. Polímeros. 2013;23(2):201-5.

10. Nock HP, Richter HG. Adesão e Adesivos. Curitiba: UFPR; 1978.

11. Pio NS. Avaliação da madeira de Eucalyptus scabra (Dum-Cours) e Eucalyptus robusta (Smith) na produção de painéis compensados. UFPR: Tese de Mestrado; 1995.

12. Keinert JS. Influência de diversos tempos de prensagem na resistência da linha de cola em compensados de açoitacavalo. Rev SCA. 1982;4:11-6.

13. European Standard. EN 204: classification of thermoplastic wood adhesives for non-structural applications. European Committee for Standardization: Bruxelas; 2004.

14. European Standard. EN 13354: Solid wood panels (SWP)_bonding quality. European Committee for Standardization: Bruxelas; 2008.

15. European Standard. COPANT 461: Determinación del peso específico aparente. Comissão Panamericana De Normas Técnicas: La Paz; 1972

16. European Standard. EN 13353: Solid wood panels (SWP)—Requirements. European Committee for Standardization: Bruxelas; 2008.

17. European Standard. EN 314-1: plywood_bond quality_test methods. European Committee for Standardization: Bruxelas; 2004.

18. USDA. The southern pines: an American wood United States. Department of Agriculture. 1985.

19. Klock U. Qualidade da Madeira de Pinus maximinoi. Moore HE. Tese de Doutorado. UFPR, Curitiba. 2000

20. Ballarin AW, Lara Palma HÁ. Propriedades de resistência e rigidez da madeira juvenil e adulta de Pinus taeda L. Arv. 2003:27(3):371-80.

21. Trianoski R, Iwakiri S, Matos JLM. Potential use of planted fast-growing species for production of particleboard. JTFS. 2011:23(3):311-7.

22. Lopes MC, Muniz GIB, Matos JLM, Tanobe VOA, Chinasso CAF, Rosso S. Resistência da linha de cola de painéis de Pinus taeda colados lateralmente com diferentes adesivos. Cerne. 2013:19(4):613-9.

\section{Submit your manuscript to a SpringerOpen ${ }^{\odot}$ journal and benefit from:}

- Convenient online submission

- Rigorous peer review

- Immediate publication on acceptance

- Open access: articles freely available online

- High visibility within the field

- Retaining the copyright to your article

Submit your next manuscript at springeropen.com 